doi: 10.15503.jecs2021.2.227.240

Journal of Education Culture and Society No. 2_2021

\title{
FORMATION AND DEVELOPMENT OF WOMEN'S SECONDARY EDUCATION IN VOLYN IN THE 19TH-THE BEGINNING OF THE 20TH CENTURY
}

\author{
OKSANA KOSTIUK \\ Department of English Language and Literature, Faculty of Romance and \\ Germanic Languages, Ostroh Academy National University \\ Seminarska 2, Ostroh, Rivnenska obl., 35800 Ukraine \\ E-mail address: oksana.kostyuk@oa.edu.ua \\ ORCID: https://orcid.org/0000-0002-9180-7162
}

\section{INNA KOVALCHUK}

Department of Indo-European Languages, Faculty of Romance and Germanic

Languages, Ostroh Academy National University

Seminarska 2, Ostroh, Rivnenska obl., 35800 Ukraine

E-mail address: inna.kovalchuk@oa.edu.ua

ORCID: https://orcid.org/0000-0002-2557-8162

\section{LESIA KOTSIUK}

Department of English Philology, Faculty of Romance and Germanic Languages

Ostroh Academy National University

Seminarska 2, Ostroh, Rivnenska obl., 35800 Ukraine

E-mail address: lesya.kotsyuk@oa.edu.ua

ORCID: https://orcid.org/0000-0003-4843-8872

\section{VIKTORIIA POLISHCHUK}

Department of Indo-European Languages, Faculty of Romance and Germanic

Languages, Ostroh Academy National University

Seminarska 2, Ostroh, Rivnenska obl., 35800 Ukraine

E-mail address: viktoriia.polishchuk@oa.edu.ua

ORCID: https://orcid.org/0000-0003-2239-1738

\section{VADYM BOBKOV}

Department of International Communication, Faculty of Romance and Germanic Languages, Ostroh Academy National University

Seminarska 2, Ostroh, Rivnenska obl., 35800 Ukraine

E-mail address: vadym.bobkov@oa.edu.ua

ORCID: https://orcid.org/0000-0003-4790-7526 


\begin{abstract}
Aim. The article aims to analyse the formation and development of women's secondary education in Volyn in the 19th-early 20th centuries under historical, sociocultural, and religious factors.

Methods. The authors describe the historical, sociocultural, and religious situation in Volyn of the late 19th-early 20th centuries and apply comparative diachronic and synchronous analyses of the charters of the educational institutions for girls, their curricula and weekly workload. Systematised pedagogical approaches to teaching and testing students of the analysed schools are used.

Results and conclusion. The formation and development of women's education in Volyn in the 19th-early 20th centuries represents a natural, consistent change in the content and structure of educational processes under certain specific historical conditions. Due to subordination changes in the region, private Orthodox boarding houses for noble girls became widespread in Volyn. Ostroh Women's Specialised School, founded by Countess Antonina Bludova, underwent a qualitative and structural transformation under the influence of specific historical events. Both Women Count D. Bludov Specialised School and the Bratsvo School aimed to raise a certified woman who can teach children at home and other educational institutions. Analysis of the statutes of educational institutions, programmes of academic disciplines, and weekly workload indicates following the educational sequence principle. In Women Count D. Bludov Specialised School, attention was paid to general disciplines in the first years of study (arithmetics, languages, geography, general history etc.). At the last stage (4th grade), students were taught pedagogy (methodology) directly related to their future profession.
\end{abstract} School

Key words: women's education, Volyn, Women Count D. Bludov Specialised

\title{
INTRODUCTION
}

\begin{abstract}
A $t$ the beginning of the third millennium, when the problem of globalisation of the mass media economy raises the question of creating a "sole world culture," it is studying regional history that inspires national self-preservation and self-identification. After all, we identify human civilisation's history with world history, barely connecting it with the regional events and features. We observe the so-called inferiority syndrome or a small person's syndrome when a person does not feel the need to be involved in world history and perceives it as illusory, externally entrenched. However, studying regional history does provide an opportunity to create the public image of national educational life. In the article, by applying comparative diachronic and synchronous analyses of the charters of the educational institutions for girls, their curricula, weekly workload, as well as by systematising pedagogical approaches to teaching and testing students of the analysed schools, we examine the historical, sociocultural, and religious situation in Volyn of the late 19th-early 20th centuries.
\end{abstract}




\section{RESEARCH INTO WOMEN'S SECONDARY EDUCATION IN VOLYN}

The formation and development of women's secondary education in Volyn took place under highly complicated political and economic circumstances and constitutes an example of the dependence of educational processes on historical, sociocultural, and religious factors. The formation and development of women's secondary education in Volyn in the 19th century represents cohesive and sequenced changes in its content and structure according to specific historical conditions.

For this exact reason, the distinguished history of cities and villages in Velyka Volyn, their place and role in the development of education, culture, and national renaissance of Ukraine have always served as the basis for scholars and local historians all time's research. The history of education of Volyn was studied by Nikolai Bykov (1915), Serhii Zhyliuk (1996), Mykola Kovalskyi (1998), Mikhail Maksymovych (1866, 1876), Anton Novoseletskyi (1999), Ivan Ohiienko (1991), Volodymyr Rozhko (2002), Nikolai Teodorovich (1901).

The most avid interest in the establishment and development of Volyn's education was expressed in the second half of the nineteenth - at the beginning of the twentieth century. In this particular period, we can find numerous works of domestic scientists: Nikolai Barsov (1863), Nikolai Bykov (1915), Ipolit Lypskii (1880), Mikhail Rodevych (1887), Nikolai Teodorovich (1901), Fedot Chetyrkin (1881). They investigate the history of establishing educational institutions.

Particular aspects of the development of women's education in Volyn in the 19th-the beginning of the 20th century were displayed in the works of Antonina Bludova (1893), Mariia Burtseva (1868), Mikhail Rodevych (1887). The authors advise on the atmosphere and educational process in the college, analyse relationships between the students and pedagogical workers of Women Count D. Bludov Specialised School, explore the reasons for establishing the educational institution for women in 1875, entrance requirements and the educational process.

There are as well modern scientific researches exploring some aspects of the development of Volyn education, namely, Nataliia Bovsunivska (2004), Oleksandr Boreiko (2004), Svitlana Brychok (2005), Liudmyla Iershova (2006), Serhii Zhyliuk (1996), Olena Karpenko (2020), Svitlana Koliadenko (1998), Oksana Kostiuk (2007), Volodymyr Omelchuk (2002), Nataliia Seiko (1999).

\section{WOMEN EDUCATION INSTITUTIONS AS THE REFLECTORS OF SOCIAL LIFE CHANGES}

Iershova, in her research work Development of women education in Volyn (late $18^{\text {th }}$-early 20th century), describes Volyn as a nationally complicated, ideologically problematic and politically unsafe region. It caused the discriminatory attitude of the tsarist government towards problems of women education for 
an extended period (Iershova, 2006). Only the educational institutions that could guarantee control over their students' minds and behaviours were supposed to expect some government financing.

It is worth mentioning that before the 1860s, there were no orthodox educational institutions for girls. Young women, even those from families of orthodox priests, were destined to be educated in catholic schools, where they were deprived of the knowledge based on their own culture and religious beliefs. Seiko states that though Polish language education was eliminated at the state level, it was still functioning in private educational institutions (Seiko, 1999).

Thus, in the territory of Volyn, there was primarily an increase in the number of boarding schools for noble girls. In the middle of the 19th century, two educational institutions of this type functioned in Zhytomyr: the first one was the Eleonora Zhdanko Boarding School founded as a parochial school; the second one was a gymnasium. According to the papers from the Office of the Governor of Volyn (Kantseliariia Volynskoho Hubernatora), in 1853, Eleonora Zhdanko Boarding School had 18 students studying Scripture (Orthodox and Catholic), Polish, German, French, Russian, calligraphy, arithmetics, music and handcrafts. The second school, where 45 girls studied, was maintained by Liubov Sokolova, a Smolnyi Institute graduate. The language of the school was Russian, while Polish was taught as a foreign language. The school curriculum included Russian, Polish, French, German, Scripture (Orthodox and Catholic versions), calligraphy, arithmetics, music, singing, dancing, handicraft, Russian and world history (Kantseliariia Volynskoho Hubernatora).

For the successful russification process and extending Moscow's orthodox Christianity in the Volyn territory, they needed clergy who would be educated and prepared specifically for the task. Rozhko (2002), in the chapter "Volyn women schools from 1864 to 1918" of his historical and country studies essay, characterised the situation of this period. He mentioned that the psychological and spiritual state of a priest greatly depended on his family life and family relationship. As a rule, the priests got educated in particular institutions, but their spouses were uneducated and very often illiterate. That is why orthodox clergy were not satisfied that local girls and women were very poorly educated and not ready for the role of a priest's wife.

Thus, under these circumstances, it was urgent to set up schools for girls from orthodox families as the situation demanded to unite local intellectuals' efforts. While trying to reach this target, since 1854, parochial authorities started to establish special schools for girls from clergy families. It became possible only within ten years when on the 20th of May 1864, such school was opened (Rozhko, 2002).

\section{VOLYN WOMEN EDUCATIONAL INSTITUTIONS}

Having studied The report on the situation in Volyn Special Religious School for Girls, we discovered that in the academic year 1872/73, the Volyn Special Religious School for Girls staff included the head of the school, the supervi- 
sor, three tutors, two tutors' assistants, three teachers of the law, music, and a doctor. At the beginning of the academic year, 84 girls were studying at the school - 44 students were granted government scholarships and 40 students were paying their expenses; there were 30 students in the junior grade, 29 in the middle grade, and 25 in the senior grade (Zvit pro stan sprav ..., 1873).

The analysis of the school curriculum reveals that the students were taught Scripture, Russian and the church Slavonic language, verbal folklore, general and Russian history, general and Russian geography, arithmetics, as well as basics of physics, calligraphy, music and church singing. It is worth noting that the teachers paid particular attention to practical methods, thus involving all the students in the learning process.

At the end of the academic year, the students had to pass exams to assess their knowledge. According to The report on the situation in Volyn Special Religious School for Girls in the 1872/1873 academic year, out of 30 students in the junior grade, 14 attained excellent marks, 11 - good marks, and 5 - satisfactory marks. Out of 29 students of the middle stage, 19 obtained excellent exam results, 7 - good results, and 3 - satisfactory results. In the senior grade, where 25 girls studied, 9 had excellent marks, 13 - good marks, 3 - satisfactory marks (Zvit pro stan sprav ..., 1873).

The main emphasis in student education was given to the religious component. The behaviour of the students was under the thorough supervision of the teaching staff. Talks and group discussions of issues from the Scripture and other holy books were regular school activities. Church and home praying was also of great importance. The girls had to attend Sunday church services and remember the importance of everyday prayer in a true Christian's life. The behaviour code encouraged modest and obedient behaviour, diligence and devotion in praying as well as politeness and kindness in communication with classmates (Zvit pro stan sprav ..., 1873).

In the academic year of 1872/1873, the school's facilities and resources included a library enriched by new textbooks and literary works. Such periodicals as Volynski Yeparkhialni Vidomosti [Volyn Diocesan Gazette] and Simeyni Vechory [The Family Evenings] were popular among the students. In the educational process, students and teachers used textbooks of the Russian authors: Russian grammar and reading book Detskii Mir [The world of kids] by Ushinskiy, the works about church services by Rudakov, Russian translations of prayers, Uchiebnaiia Teoriia Slovesnosti [The educational theory of language arts] by Minin, Russian grammar by Govovrov and Ridne Slovo [The native word] (Zvit pro stan sprav ..., 1873).

A considerable contribution to the development of religious education was made by countess Antonina Bludova, a well-known writer, educator and philanthropist. She was also a co-founder of the orthodox Kyrylo-Metodiivske Bratstvo (1866), the first secondary specialised school for women in the Volyn area, named in honour of Count D. Bludov (1866), a library (1865), and the Kyrylo-Metodiivske Bratstvo church. Bludova was also well-acquainted with prominent writers, cultural figures and scientists; she was also respected by 
the best representatives of Ukrainian and Russian intellectuals of the second half of the 19th century. Bludova wrote works on religious and ethical issues and prepared translations of theological works by foreign authors, which were published under her own name or pseudonym "Nikolay Rebrovskiy" in the Strannik [The Stranger] journal and a newspaper Volynski Yeparkhialni Vidomosti [Volyn Diocesan Gazette]. Her most well-known work "Vospominaniya" [The Memories] was published in Russkiy Arkhiv [Russian Archive] in 1872-76, and 1878-1889 (Bludova, 1893).

Countess Bludova paid particular attention to establishing Ostroh Women Specialised School for girls from orthodox families of different social stratum under the aegis of Kyrylo-Metodiivske Bratstvo. Students of the school were supposed to be taught the basics of good housekeeping and obtain an education based on the basic principles of orthodox Christianity, forming and developing personality with a sacral mindset. On 1 December 1865, studies in preparatory class with six students began.

According to the Preparatory Class Curriculum, the students studied the Divine law, sacred history combined with law lessons, Russian and French languages, arithmetics and geography, how to write, pray, and read the Gospel. This preparatory class served as the basis for the Women Specialised School named after Count D. Bludov (Bykov, 1915).

In 1866, the School had the first incomplete class; studying in this class was supposed to take two years. The administration developed the School Code of Conduct. The first variant of the Code consisted of nine paragraphs, which later was extended with new ones, and defined the aims and tasks of the school, conditions and requirements of entering the School and promotion to a higher grade, and the examination processes (Rodevych, 1887).

According to Paragraphs 7-9 of the Code, the School included four grades: the 1st and 2nd grade lasted for two years, the 3rd and 4th grades for one year. The girls accepted into the school were orthodox Christians. To become a first-grade student, a girl had to be from 6 to 15 years old; at the age of 18 to 20 , one could be a student at two higher grades. Admission to the first grade took place every two years. The exception could be made if a girl seeking admission could pass exams in all required subjects before entering. In 1872, forty students lived on the School's campus, and 52 girls attended school while being city dwellers.

During the first years, the School teaching staff included the head, her two assistants, a tutor teaching Russian and French languages and Russian history, a music teacher, a supervisor from the brotherhood school leading the preparatory class, and her assistant. Moreover, some teachers did not live on the school's territory.

In 1872 the first graduation at the School took place (Bykov, 1915). Among the first School graduates were: Yelizaveta Silvestrova, Yelizaveta Grigoryeva, Stephanida Kovalevska, Teklia Berezhnytska, Aphanasiia Nemolovska and Yuliia Khrzhanovska. As the School was a private educational institution, all the graduates had to take exams in the gymnasium course at Ostroh 
Progymnasia. Three of the School graduates, Yelizaveta Silvestrova, Teklia Berezhnytska and Aphanasiia Nemolovska passed the exams with flying colours and received excellent marks in the Russian language, Divine law, history and wrote essays "Thoughts on Graduating from the School." Also, four students were awarded the qualification "Home teacher." Later Yuliia Khrzhanovska joined them on her completion of the course (Bykov, 1915).

In 1872, Shchepetilnikova, former Head of Novokhoperska Progymnasia in Voronezh Province, was appointed the School's Head. On her arrival, the learning process became better and more stable, even though staff turnover caused low academic performance and a stressful school environment. In spring 1873, no students were registered to pass the qualification exam for "Home Teacher" (Rodevych, 1887).

Analysis of the sources enables us to conclude that the psychological situation and relationships between teaching staff were not always friendly; frequent misunderstandings between the head and her assistant and the teachers themselves negatively impacted the students' behaviour. Countess Bludova, trying her best to improve the situation, encouraged the head assistant to solve the underlying problems by seeking "reconciliation, tolerance, Christian love - life rules for every Christian, and us - women, who have more difficulties and obstacles in life then men do" (Rodevych, 1887, p. 244).

In 1873, the Ministry of Education inspected the School. In April 1875, according to the inspection results, the Ministry of Public Education took control over the School and renamed it The Count D. Bludov Women Specialised School. The School preserved its main characteristics and went on to function as a closed religious school, which gave the girls from the city the right to attend school classes.

The Ministry of Public Education provided the School with the annual financial support of 1500 roubles. Additionally, the Ministry drew up and finalised the School Code and issued a special Instruction according to which the school's guidance had to be done. They settled the School's teaching staff and designed the School Curriculum (Instruktsiia ..., 1876). The School Code included 32 main rules and explanations, some amendments extending the previous School Code (1867), and "The rules for those who seek admission to Count D. Bludov Women Specialised School under the aegis of KyryloMetodiivske Bratstvo in the town of Ostroh" (Sviedeniia ..., 1873). The School consisted of four grades with seven years of studies.

Paragraphs 4 and 11 of the Code stated that the first three grades lasted for two years each, and the senior one for a year. Girls aged 9 to 13 were accepted to junior grades (older girls could be taken to the senior grade) if they belonged to the orthodox Christian faith, which was the main requirement for acceptance. The School Curriculum for each grade was developed by the School staff and signed by the Ministry of Public Education (Rodevych, 1887). Admission to the first grade took place every two years, except when a girl seeking admission could pass exams in all the subjects she had mastered before her entry. 
According to the requirements of the new Code, candidates seeking admission were to have basic knowledge of the Divine Law (be able to read essential prayers), be able to read in a Slavonic language, read fast in Russian and retell, write dictations without changing the words and missing letters, differentiate parts of speech and parts of the sentence, count to 100, write four-digit numbers, be aware of the first two operations of arithmetics and be able to read in French. Those girls who intended to enter higher grades (2nd, 3rd and 4th) had to pass exams in all the subjects studied in previous years (Rodevych, 1887).

The main rules of the School Code defined the subjects that were to be studied: the Divine law, church Slavonic and Russian languages, language arts, an abridged history of Russian literature with essays about foreign literature, general and Russian history, geography, arithmetics, basic notions of physical phenomena, French, pedagogics, calligraphy, handicrafts, music and singing (mostly church singing). Students of the senior grade had teaching internship in the Brotherhood School (Sviedeniia ..., 1873). Paragraph 17 of the School Code states that the students of the 4 th grade having excellent results could do practical tasks. After finishing the course, they could be awarded the "Home Teacher" qualification without any additional exam; those students who studied the general course were given a certificate of "Home Teacher" only in the subjects in which they passed exams successfully.

Countess Bludova worked out the main educational principles and identified the main directions and pastoral work rules (Instruktsiia ..., 1876) The rules for teaching staff and academic programmes in school subjects were also developed.

On 11 September 1876, the Public Education Assistant Minister signed the academic programmes for the Divine law, Russian language and language arts, church Slavonic language, Russian history, general history, geography, arithmetics, French language, history of literature (Probni prohramy ..., 1876). Each of the programmes included topics and smaller units according to the course of studies.

In Tables 1 and 2 (Probni prohramy ..., 1876), we present the examples of the programmes in French language and history of literature: 
Journal of Education Culture and Society No. 2_2021

Table 1

Academic Programme in the French language

\begin{tabular}{cl}
\hline $\begin{array}{c}\text { Year and grade of } \\
\text { studies }\end{array}$ & \multicolumn{1}{c}{ Content } \\
\hline 1st grade (1st year) & $\begin{array}{l}\text { reading and writing, elementary oral and written translation } \\
\text { from French into Russian, learning simple poems by heart } \\
\text { reading and translation from Russian into French and vice versa } \\
\text { 1st grade (2nd year) } \\
\text { 2nd grade (1st year) } \\
\text { writing dictations and introduction of grammar rules, i.e. basic } \\
\text { predicate and conjugation of auxiliaries }\end{array}$ \\
2nd grade (2nd year) & $\begin{array}{l}\text { reading and retelling - oral and written; dictation and grammar } \\
\text { analysis } \\
\text { teaching etymology like a system; dictation and written } \\
\text { 3rd grade (1st year) } \\
\text { exercises; syntaxes, written exercises, reading and translation } \\
\text { from special books in reading } \\
\text { introduction into French classical literary works; oral and } \\
\text { written translations from Russian into French for practical } \\
\text { usage of studied grammar rules and developing language skills } \\
\text { Practical classes: colloquial language and teaching in the } \\
\text { Brotherhood School }\end{array}$ \\
4th grade & 1876 year)
\end{tabular}

Source: Probni prohramy ..., 1876

History of literature was taught in the 3rd grade, which one can see from Table 2:

Table 2

Academic Programme in History of literature

\begin{tabular}{ll}
\hline $\begin{array}{c}\text { Year and grade of } \\
\text { studies }\end{array}$ & \multicolumn{1}{c}{ Content } \\
3rd grade (1st year) & Ancient literature: Indian, Jewish, Persian, Greek, Latin \\
3rd grade (2nd year) & New literature: Italian, French, Portuguese, Spanish, \\
& $\begin{array}{l}\text { German, English, Swedish, Danish, Czech, Polish, Serbian. } \\
\text { Essays in the literature aimed to present the systems of } \\
\text { views and values of different folks and, mainly, positive } \\
\text { ideas of their life worth following }\end{array}$ \\
\hline
\end{tabular}

Source: Probni prohramy ..., 1876

Analysis of the presented programmes enables us to conclude that studying in the 1st, 2nd and 3rd grade lasted for two years at each stage and for a year in the 4 th grade. The programme was taught in a logical, coherent way, beginning from the simplest things and moving towards more complex and then the most complicated ones and was according to the level of students and year of their studies. It is worth mentioning that besides the thematic division of the material, there was also a weekly learning hours load, which we present in Table 3. 
Table 3

Weekly learning hours load in Ostroh D. Bludov Women School

\begin{tabular}{|c|c|c|c|c|c|c|c|c|}
\hline \multirow[t]{3}{*}{ Subjects } & \multicolumn{7}{|c|}{ Grade } & \multirow[t]{3}{*}{ Total } \\
\hline & \multicolumn{2}{|c|}{1 st } & \multicolumn{2}{|c|}{ 2nd } & \multicolumn{2}{|c|}{$3 \mathrm{rd}$} & 4 th & \\
\hline & $\begin{array}{c}1 \text { st } \\
\text { year }\end{array}$ & $\begin{array}{l}\text { 2nd } \\
\text { year }\end{array}$ & $\begin{array}{l}1 \text { st } \\
\text { year }\end{array}$ & $\begin{array}{l}\text { 2nd } \\
\text { year }\end{array}$ & $\begin{array}{l}1 \text { st } \\
\text { year }\end{array}$ & $\begin{array}{l}\text { 2nd } \\
\text { year }\end{array}$ & & \\
\hline Divine law & 2 & 2 & 2 & 2 & 2 & 2 & 2 & 14 \\
\hline $\begin{array}{l}\text { Slavonic language } \\
\text { and reading }\end{array}$ & 2 & 2 & & 2 & 2 & 1 & 1 & 10 \\
\hline Russian language & 6 & 5 & 5 & 4 & 2 & 2 & 1 & 25 \\
\hline Russian history & 3 & 3 & 3 & 3 & 3 & 3 & 2 & 20 \\
\hline Geography & 2 & 2 & 2 & 2 & 2 & 2 & & 12 \\
\hline Arithmetics & 2 & 2 & 2 & 2 & 2 & 2 & 2 & 14 \\
\hline French language & 4 & 3 & 3 & 3 & 3 & 3 & 2 & 21 \\
\hline General history & & 3 & 3 & 3 & 3 & 3 & 2 & 17 \\
\hline $\begin{array}{l}\text { Theory of } \\
\text { language arts }\end{array}$ & & & & & 2 & & & 2 \\
\hline Russian literature & & & & & & 2 & 2 & 4 \\
\hline $\begin{array}{l}\text { Essays in general } \\
\text { literature }\end{array}$ & & & & & 2 & & 2 & 4 \\
\hline $\begin{array}{l}\text { Physical } \\
\text { geography and } \\
\text { basics in physics }\end{array}$ & & & & & & 2 & 2 & 4 \\
\hline Pedagogies & & & & & & 2 & 2 & 4 \\
\hline Calligraphy & 2 & 1 & 2 & 1 & & & & 6 \\
\hline Singing & 2 & 2 & 2 & 2 & 2 & 2 & & 12 \\
\hline Handicraft & 2 & 2 & 3 & 3 & 2 & 2 & & 14 \\
\hline Total: & 27 & 27 & 27 & 27 & 27 & 30 & 18 & 182 \\
\hline
\end{tabular}

Source: Rozklad ..., 1886-1887

The data in Table 3 shows that Ostroh D. Bludov Women School followed the principle of coherence. During the first years of studies, the students had the basic subjects - arithmetics, languages, geography, general history, etc., while the last year's disciplines dealt with the future teaching profession, i.e. pedagogies and methods of teaching. singing, calligraphy and handicraft were not included in the curriculum of the $4^{\text {th }}$ grade.

The School followed a fixed daily routine: the students woke up at 7 a.m., prayed till eight and had breakfast. From 8:45 a.m. till 9:00 a.m., they would listen to someone read the New Testament with further explanation and singing Troparion to St. Kyrylo and Mephodiy. Classes lasted from 9 a.m. till 2:30 p.m. After classes, at 4 p.m., the students had dinner and some rest. From 6 p.m. till 7:30 p.m., the girls were doing their homework and preparing for the next day. Their supervisors were giving necessary help to those students who had particular difficulties with their studies. At 7:30 p.m., the students had supper. At 9:00 p.m., they attended church service where they prayed for the 
Emperor, the Empress, the Imperial Home, Benefactor of the School, the Head of the School, the Head Assistant of the School, teachers, supervisors and students. Curfew was at 10:00 p.m. (Bykov, 1915).

The School Code, staff restructuring, advanced curriculum and programmes considerably improved the education process. It gave the School administration more opportunities to invite the best teachers of the current period. For example, Countess Bludova invited an archpriest Yakiv Nemolovskiy, the KyryloMetodiivske Bratstvo Church's arch-presbyter, for the law teacher's position. Shchepetilnikova, a talented and experienced educator, has worked as the School Head since 1872, assisted by Torburg, a prominent pedagogue of the period.

Every year number of students eager to study at the School was increasing. In 1876, 26 girls entered the School, but only 13 could finish their education. Russian was the language of teaching at the School. This circumstance urged Bludova to ask the rector of Petrograd Ecclesiastical Academy Yanishev and Professor Koyalovich to recommend a teacher of the Russian language for the School. Kutnevich, who got good credentials from these well-known educators, became the School Russian language teacher. He initiated a new discipline, "Methods of Teaching at Junior School," in the $4^{\text {th }}$ grade (Bykov, 1915).

Thus, the educational process kept high-level standards, which is why the number of applicants seeking admission to the School was gradually increasing. But because of lack of premises, many of them got a refusal. The facts are that in 1878, there were 166 students instead of 80 . As a result of the situation, the School administration decided not to accept any students for four years. They aimed to reach the number of 58 girls on the boarding schooling and 22 students who attended the School but lived at home (Otchiot..., 1882).

From the school foundation (1865) till 1 January 1915, 1,747 students studied there, and 27 girls entered the additional 8th grade. Thus, the total number of students was 1,774. They belonged to different socio-economic strata: children of the nobility and civil servants - 876, daughters of clergy - 490, girls from the families of merchants, lower middle class and craftsmen - 231, and from peasant class 177 students. The total number of students at the School within a 2-year course of studies in one grade was not more than 200 girls. After introducing the new Code, the number of students was constantly increasing, and in the 1914/1915 academic year, it was 333 . The number of girls who finished their studies successfully since 1872 (the year of the first graduation) was 667, including 198 8th grade students. Over the entire period of School's existence, 1,171 students studied there.

In 1916 because of the difficulties of the wartime, the School was evacuated to Poltava province. After coming back to Ostroh, the School had only a few students. In March 1921, Volyn joined Poland, and in 1923 the School was closed by the Polish government.

It is worth mentioning that the Kyrylo-Metodiivske Bratstoo School that worked under the Women Specialised School's aegis had its own Code and Curriculum. According to its Code, the Bratstvo School had two grades, and there were academic programmes for each one. The enrolment to the Bratstvo School happened every year, and studying here was considered the preparation to enter 
Count D. Bludov Women Specialised School. However, there was no definite duration of studying period in the Bratstvo School. Since the age of applicants seeking admission was not clearly defined, in the first grade, the girls from 9 to 22 years old could study. In upcoming years, the following classes were open - the $2^{\text {nd }}$ grade in 1868, with two years of studies, the $3^{\text {rd }}$ grade in 1870 , and the $4^{\text {th }}$ grade in 1872. The rules for applicants seeking admission to Ostroh Count Bludov Women Specialised School were laid down (Bykov, 1915).

On the 12th of December, 1882, the Bratstvo School, working as a preparatory educational institution for entry to the Count D. Bludov Women Specialised School, was transformed into an independent three-year school with an extended curriculum (Rodevych, 1887). According to the Bratstvo Women School Code, it aimed at educating teachers for village parochial and public schools. To make it work out well:

- the Bratstvo School consisted of three departments; the junior one was a preparatory class for the Women Specialised School;

- students who, after finishing the Bratstvo School, were evaluated not less than 4 points, except for the singing, had the right to work as parochial school or public school teachers; it was certified by the Bratstvo Council;

- the Bratstvo School was managed by the Head of Count D. Bludov Women Specialised School;

- the subjects at school were the Divine law, Russian and Slavonic languages, arithmetics, calligraphy, geography, singing;

- there was a weekly number of lessons for each subject (see Table 4):

Table 4

Weekly load in the Bratstoo School

\begin{tabular}{l|c|c|c}
\hline Subject & \multicolumn{3}{c}{ GRADE } \\
\cline { 2 - 4 } Scripture & 1st grade & 2nd grade & 3rd grade \\
Russian language & 4 & 3 & 3 \\
Slavonic language & 5 & 6 & 6 \\
Arithmetics & 3 & 2 & - \\
Calligraphy & 3 & 3 & 3 \\
Singing & 2 & 2 & 1 \\
Handicraft & 2 & 2 & 2 \\
Geography & 8 & 8 & 7 \\
History & - & 1 & 2 \\
\hline Total per week: & 1 & 28 & 4 \\
\hline
\end{tabular}

Source: Rodevych, 1887

Thus, according to the weekly load and the curriculum, the students of the first grade of the Bratstvo Women Specialised School studied the Divine law (interpretation of prayers and the most important holidays, history of New and Old Testament by the books for reading in junior grades of St. Kyrylo-Metodiivske Brat- 
stvo), Russian history, Russian language (dictation; grammar - Noun, Adjective, Pronoun, Verb), Slavonic language (reading books in church Slavonic language with the translation of the words not found in Russian), arithmetics (four operations with simple numbers and doing sums), calligraphy, singing and handicraft.

In the second grade, students studied the following subjects: the Divine law (history of New and Old Testament, church service in orthodox church), Russian language (simple and complex sentences, Numeral, Adverb, Preposition, Conjunction, subordinate clauses, dictation with grammar analysis), Slavonic language (reading with an explanation of numbers and special marks), arithmetics (common fractions), abridged Russian history, geography (basic notions, Russian geography without division into provinces), calligraphy, singing and handicrafts.

In the third grade, the students learned the Divine law (revision), Russian language (main rules of orthography and sequence of words, writing - letters, requests, messages), arithmetics (four operations with ordinary fractions, doing sums, introduction to decimal fractions), geography (description of provinces and main cities of Russia, introduction into central European and Asian countries with their capital cities), general history of Russia, calligraphy, singing, handicraft (Bykov, 1915).

Since the institution's main task was to give students proper knowledge and instil high moral values, great attention was paid to prayer so that it would form a spiritual type of thinking. That is why on weekends and holidays, all the students, without any exception, had to be present at the general church prayer. On Saturdays and the eve of big holidays, after night prayer, pupils were not allowed to dance, sing secular songs or take part in theatrical performances. Similar requirements were set for teachers to set a positive example, the first rule of education (Instruktsiia ..., 1876).

\section{CONCLUSIONS}

The study of the history of the establishment and development of education in Volyn will help understand the educational processes in Ukraine in the 19th century more deeply. From ancient times, Volyn and Halych land were outposts of the East Slavs education and culture in the west of Ukraine-Rus. The Women's School of Count D. Bludov in Ostroh became one of the centres of women's education in Volyn in the second half of the 19th century. This school's pupils became home teachers, educating children and adults in private and public schools in Volyn. The school fulfilled its primary task, which, long before its opening, was provided by Count Bludov - education of girls in the spirit of Orthodoxy and dissemination of women's education in the region. The school's pupils defended their parents' faith, raised their children in holiness and obedience, and became good, modest women and caring mothers. To ensure educational activities, teachers at women's theological schools in Volyn used various methods, techniques, tools, and explanatory exercises that effectively influenced success and education. A special place in the educational process was given to conversation and personal example. 


\section{REFERENCES}

[1] Barsov, N. (1863). Otchiot o poiezdke s pedagogicheskoi tseliiu po Volyni i Podolii [Report on a trip with a pedagogical purpose to Volyn and Podolia]. Sankt-Peterburg: Tipografiia Moskoho Ministerstva.

[2] Bludova, A. (1893). Vospitannitsam uchilishcha gr. D. N. Bludova ot Popechytelnitsy na proshchaniie [A farewell note to the pupils of women specialised school named after D. Bludov from the Trustee]. Kiev: Tipografiia V. M. Byrzhykovskoho.

[3] Boreiko, O. (2004). Prosvitnytsko-pedahohichna diialnist hromadskykh tovarysto Volyni (dp. pol. XIXpoch. XX cm.) [Educational and pedagogical activity of public societies of Volyn (second half of the 19th - beginning of the 20th century)]. [Doctoral dissertation, Zhytomyr State University named after Ivan Franko]. Library Fund of Zhytomyr State University named after Ivan Franko.

[4] Bovsunivska, N. (2004). Rozoytok shkilnoii myzuchnoii osvity na Volyni (kinets XIX-poch. XX st.) [Development of school music education in Volyn (end of the 19th - beginning of the 20th century)]. [Doctoral dissertation, Zhytomyr State University named after Ivan Franko]. Library Fund of Zhytomyr State University named after Ivan Franko.

[5] Brychok, S. (2005). Tserkovnoparafiialni shkoly $v$ systemi pochtkovoi osvity na Volyni (dryha polovyna XIX-20-ti rr. XX stolittia) [Church-parish schools in the system of primary education in Volyn (second half of the 19th - 20s of the 20th century)]. [Doctoral dissertation, Zhytomyr State University named after Ivan Franko]. Library Fund of Zhytomyr State University named after Ivan Franko.

[6] Burtseva, M. (1868). Svedieniia ob uchilishchie nakhodiashchemsia pri Ostrozhskom Kirrilo-Mefodiievskom Bratstvie, v pamiat grafa Bludova i o bratskoi prihodskoi shkolie i aptieke: Iz pisma k Agafangely arkhiepiskopu Volynskomu i Zhytomiskomu, ot 6 aprielia 1868 goda [Notes on the Specialised School at Ostroh Kyrylo-Metodiivske Bratstvo on memorising Count Bludov and Brotherhood School and Apotheke: From the letter to Archbishop of Volyn and Zhetomyr Region Agafangel, of April 6, 1868], Volynski ieparkhialni vidomosti, 17, 479-482.

[7] Bykov, N.P. (1915). Piatidesiatilietiie Ostrozhskoho Sv. Kirillo-Mefodiievskoho pravoslavnoho tserkounoho bratstva 1865-1915 gg.: Istoricheskaia zapiska [The fiftieth anniversary of Ostroh St. Kyrylo and Methodii Orthodox Church Brotherhood 1865-1915: Historical notes]. Petrograd: Tipografiia V.F.Kirshbauma.

[8] Chetyrkin, F. (1881). Istorychnyi narys Volynskoii dukhovnoii seminarii [Historical essay on Volyn Theological Seminary]. Volynski ieparkhialni vidomosti, 34, 1141-1148.

[9] Iershova, L. (2006). Rozvytok zhinochoi osvity na Volyni (kinets XVIII-pochatok XX stolittia) [Development of women education in Volyn (late $18^{\text {th }}$-early 20th century)]. Zhytomyr: Polissia.

[10] Instruktsiia Dlia upravlinnia uchylyshchem im. hrafa Dmytra Mykolaiovycha Bludova v m. Ostrozi [Instruction for the management of the Specialised School of Count Dmitriy Nikolaievich Bludov in Ostroh]. (1876). Derzhavnyi arhiv Volynskoi oblasti [State Archive in Volyn Oblast] (Section 3, Box 1, Folder 11), Lutsk, Ukraine.

[11] Kantseliariia Volynskoho Hubernatora [Office of Volyn Governor]. Derzhavnyi arhiv Zhytomyrskoii oblasti [State Archive in Zhytomyr Oblast] (Section 70, Box 1, Folder 1114), Zhytomyr, Ukraine.

[12] Karpenko, O. (2020). The formation of the Christian outlook of the student youth in Volhynia province (19th - early 20th century). Human Studies. Series of Pedagogy, 10(42), 113-121. doi: https://doi.org/10.24919/2413-2039.10/42.198829

[13] Koliadenko, S. (1998) Zmist ta orhanizatsiia diialnosti Kremenetskoho litseiu iak oseredku osvity na Volyni (1805-1933 rr.) [Content and organisation of activity of Kremenets Lyceum as a centre of education in Volyn (the years 1805-1933)]. [Doctoral dissertation, Pedagogical Institute of the National Academy of Pedagogical Sciences of Ukraine]. Library Fund of Pedagogical Institute of the National Academy of Pedagogical Sciences of Ukraine.

[14] Kostiuk, O. (2007). Stanovlennia ta rozoytok relihiinoi osvity na Volyni (XIX - poch. XX st.). [Formation and development of religious education in Volyn]. [Doctoral dissertation, Zhytomyr State University named after Ivan Franko]. Library Fund of Zhytomyr State University named after Ivan Franko.

[15] Kovalskyi, M. (1998). Malovidoma storinka z istoriii zhinochoii osvity v Ostrozi na pochatku XX st. [Little-known page on the history of women's education in Ostroh in the early twentieth century] In: M. Kovalskyi (Ed.), Etiudy z istorii Ostroha: Narysy. [Essays on the history of Ostroh] (pp. 169-178). Ostroh: Ostrozka Akademiia. 
[16] Lypskii, I. (1880). Den otkrytiia Volynskoi dukhovnoi seminarii [Opening day of Volyn Theological Seminary], Volynski ieparkhialni vidomosti, 36, 1627-1632.

[17] Maksymovych, M. (1866). Pisma o kniaziakh Ostozhskikh $\kappa$ grafinie A. D. Bludovoi. [Letters about Princesses Ostrozhskih to Count A. Bludova]. Kiev: Tipografiia MP Fritsa.

[18] Maksymovych, M. (1876). Pisma o kniaziakh Ostrozhskikh к grafinie A. D. Bludovoi [Letters about Princesses Ostrozhky to Count A. Bludova]. In: M. A. Maksymovych (Ed.), Sobraniie sochinienii, V. 1: Otdel istoricheskii [Collected works: Historical part] (pp. 164-199). Kiev: Tipografiia MP Fritsa.

[19] Novosiletskyi, A. (1999). Ostroh - tsentr osvity na Volyni (XIX st.) [Ostorh - the educational centre in Volyn (19 ${ }^{\text {th }}$ century)]. In: A. Novosiletskyi (Ed.), Ostroh na Volyni: Nauk-popul. narys z naidavnishykh chasiv do pochtku XX st [Ostroh from Volyn: Science-popul. essay from ancient times to the beginning of the twentieth century] (pp. 91-106). Ostroh: Ostrozka Akademiia.

[20] Ohiienko, I. (1991). Ukraiinska kultura: Korotka istoriia kulturnoho zhyttia ukraiinskoho narodu. Z maliunkamy i portretamy ukraiinskykh kulturnykh diiachiv [Ukrainian culture: A short history of Ukrainian people cultural life. With painings and portraits of Ukrainian culture figures]. Kyiv: Abrys.

[21] Omelchuk, V. (2002). Rozvytok osvity na Volyni (dr. pol. XIX - poch. XX st.) [Development of education in Volyn]. [Doctoral dissertation, The National Pedagogical University named after Mykhailo Drahomanov]. Library Fund of The National Pedagogical University named after Mykhailo Drahomanov.

[22] Otchiot Sv. Kirrilo-Mefodievskoho pravoslavnoho tserkovnoho bratstva za 1878-1879 gg [Report of St. Kyrylo-Methodiivske Orthodox Church Bratstvo for the years 1878-1879]. (1882). Sant-Peterburg: Tipografiia Glazunova.

[23] Probni prohramy Ostrozkoho, sv. Kyrylo-Mefodiivskoho, zhinochoho uchylyshcha, hrafa Bludova. [Trial programmes of Ostroh St. Kyrylo-Methodiivske Bratstvo Women Specialised School of the Count Bludov]. (1873). Volynski ieparkhialni vidomosti, 24, 730-748.

[24] Rodevych, M. (1887). Zhenskoie grafa Dmitriia Nikolaievicha Bludova uchilishche v gorode Ostroge. Sbornik deistvuiushchikh v niom postanovlenii, rasporiazhenii, program, pravil i pr. s 1866 po 1886 g. v 2-ukh chstiakh [Women Specialised School of Count Dmitriy Nikolaievich Bludov in the city of Ostroh. A collection of decrees, orders, programmes, rules, etc., operating from 1866 to 1886, in 2 parts], Zhurnal Ministerstva Narodnoho Prosveshcheniia, 189, 45-71.

[25] Rozhko, V. (2002). Volynske divoche uchylyshche 1864-1918 rr. [Volyn Girls' School in 1864-1918]. In: V. Rozhko (Ed.), Dukhovni pravoslavni osvitni zaklady Volyni X-XX st.: Istoryko-kraieznavtchyi narys [Spiritual Orthodox educational institutions of Volyn of the 10th-20th centuries: Historical and culture studies essay]. Lutsk: Media.

[26] Rozklad urokiv Ostrozkoho zhinichoho hrafa D. M. Bludova uchylyshcha v 1886-1887 rr. [Lessons schedule of Ostroh D. Bludov Women School of Count in 1886-1887]. ЦДІАУК. [Central State Historical Archive of Ukraine] (Section 707: Kantseliariia popechytelia Kyiivskoho navchalnoho okruhu [Office of the Trustee of Kiev Educational District], Box 296, Folder, 37, pp. 24-26), Kyiv, Ukraine.

[27] Seiko, H. (1999). Pedahohichni ta etnosotsiolohichni zasady rozoytku polskoho shkilnytstva na VolyniZhytomyrshchyni u 1905-1938 rr. [Pedagogical and ethnic-sociological principles of development of Polish schooling in Volyn-Zhytomyr region in 1905-1938]. [Doctoral dissertation, Pedagogical Institute of the National Academy of Pedagogical Sciences of Ukraine]. Library Fund of Pedagogical Institute of the National Academy of Pedagogical Sciences of Ukraine.

[28] Sviedeniia dlia postupaiushchikh v uchilishche grafa D. N. Bludova, pri sv. Kirrilo-Mefodiievskom bratstvie $v g$. Ostroge. [The information for those who seek admission to Count D. Bludov Women Specialised School under the aegis of Kyrylo-Metodiivske Bratstvo in the town of Ostroh]. (1873). Volynski ieparkhialni vidomosti, 24, 726-730.

[29] Teodorovich, N. (1901). Volynskaiia dukhornaia seminariia [Volyn Theological Seminary]. Pochaiev: Tipographiia Pochaievskoi Uspenskoi Lavry.

[30] Zhyliuk, S. (1996). Rosiiska tserkva na Volyni u 1793-1917 rr. [Russian church in Volyn in the years 1793-1917]. Zhytomyr: Zhur. fond. redktsii hazety Klych.

[31] Zvit pro stan sprav Volynskoho uchylyshcha dlia divchat dukhovnoho stanu [The report on the situation in Volyn special religious school for girls]. (1873). Volynski ieparkhialni vidomosti, 24, 630-636. 